\title{
Documentation of a Collection of Archaeological Materials from the Millsey Williamson Site (41RK3), A Historic Nadaco Caddo Settlement
}

Timothy K. Perttula

Heritage Research Center, Stephen F. Austin State University

Bo Nelson

Heritage Research Center, Stephen F. Austin State University

Follow this and additional works at: https://scholarworks.sfasu.edu/ita

Part of the American Material Culture Commons, Archaeological Anthropology Commons, Environmental Studies Commons, Other American Studies Commons, Other Arts and Humanities Commons, Other History of Art, Architecture, and Archaeology Commons, and the United States History Commons

Tell us how this article helped you.

This Article is brought to you for free and open access by the Center for Regional Heritage Research at SFA ScholarWorks. It has been accepted for inclusion in Index of Texas Archaeology: Open Access Gray Literature from the Lone Star State by an authorized editor of SFA ScholarWorks. For more information, please contact cdsscholarworks@sfasu.edu. 
Documentation of a Collection of Archaeological Materials from the Millsey Williamson Site (41RK3), A Historic Nadaco Caddo Settlement

\section{Creative Commons License}

\section{(c) (1) \&}

This work is licensed under a Creative Commons Attribution-NonCommercial 4.0 International License 


\title{
DOCUMENTATION OF A COLLECTION OF ARCHAEOLOGICAL MATERIALS FROM THE MILISEY WILLIAMSON SITE (41RK3), A HISTORIC NADACO CADDO SETTLEMENT
}

\author{
Timothy K. Perttula and Bo Nelson
}

\section{Introduction}

The Millsey Williamson site (41RK3) is a well known historic $18^{\text {th }}$ century Nadaco Caddo site on Martin Creek in Rusk County, Texas (Jones 1968:62-84). It is one of a number of $18^{\text {th }}$ and early $19^{\text {th }}$ century Kinsloe phase sites in the middle Sabine River basin (Perttula 2006: Figure 312) apparently affiliated with the Nadaco Caddo settlement of the region.

An unknown number of historic Nadaco Caddo burials have been excavated at the site over the years, especially along the western part of the terrace landform above Martin Creek (Jones 1968: Figure 5), now marked by the Martin Lake shoreline. There has been intensive collecting activities at Millsey Williamson since Martin Lake was built more than 30 years ago. The collection we document here came from the shoreline in the general area of the other Nadaco Caddo burials reported from Millsey Williamson.

\section{The Collection}

The collection from the Millsey Williamson site includes three ceramic vessels, one unidentified lead fragment ( $52 \times 19 \mathrm{~mm}$ in length and width and $4.8 \mathrm{~mm}$ thick, possibly a large piece of lead sprue), 36 glass beads, and 40 plain or decorated ceramic vessel sherds.

Vessels

Vessel 1 is a simple bowl (Table 1) with nine irregular rows of tool punctations that extend from the rim to the vessel base (Figure 1). The rim is direct with a rounded lip. Punctated vesscls are common utility wares in Kinsloe phase burial assemblages (see Perttula 2007, this volume). 
Table 1. Millsey Williamson vessels.

\begin{tabular}{llllll}
\hline Vessel No. & Temper & Firing Height $(\mathrm{cm})$ & $\begin{array}{l}\text { Orifice } \\
\text { Diameter } \\
(\mathrm{cm})\end{array}$ & $\begin{array}{l}\text { Thickness at rim } \\
\text { (in mm) }\end{array}$ \\
\hline 1 & none & F* & 7.9 & 13.0 & 4.6 \\
2 & bone & G & 4.0 & 7.1 & 4.3 \\
3 & grog & F & 9.3 & 7.3 (body) & 4.8 \\
\hline
\end{tabular}

*F and G: fired in an oxidizing environment, but cooled in the open air

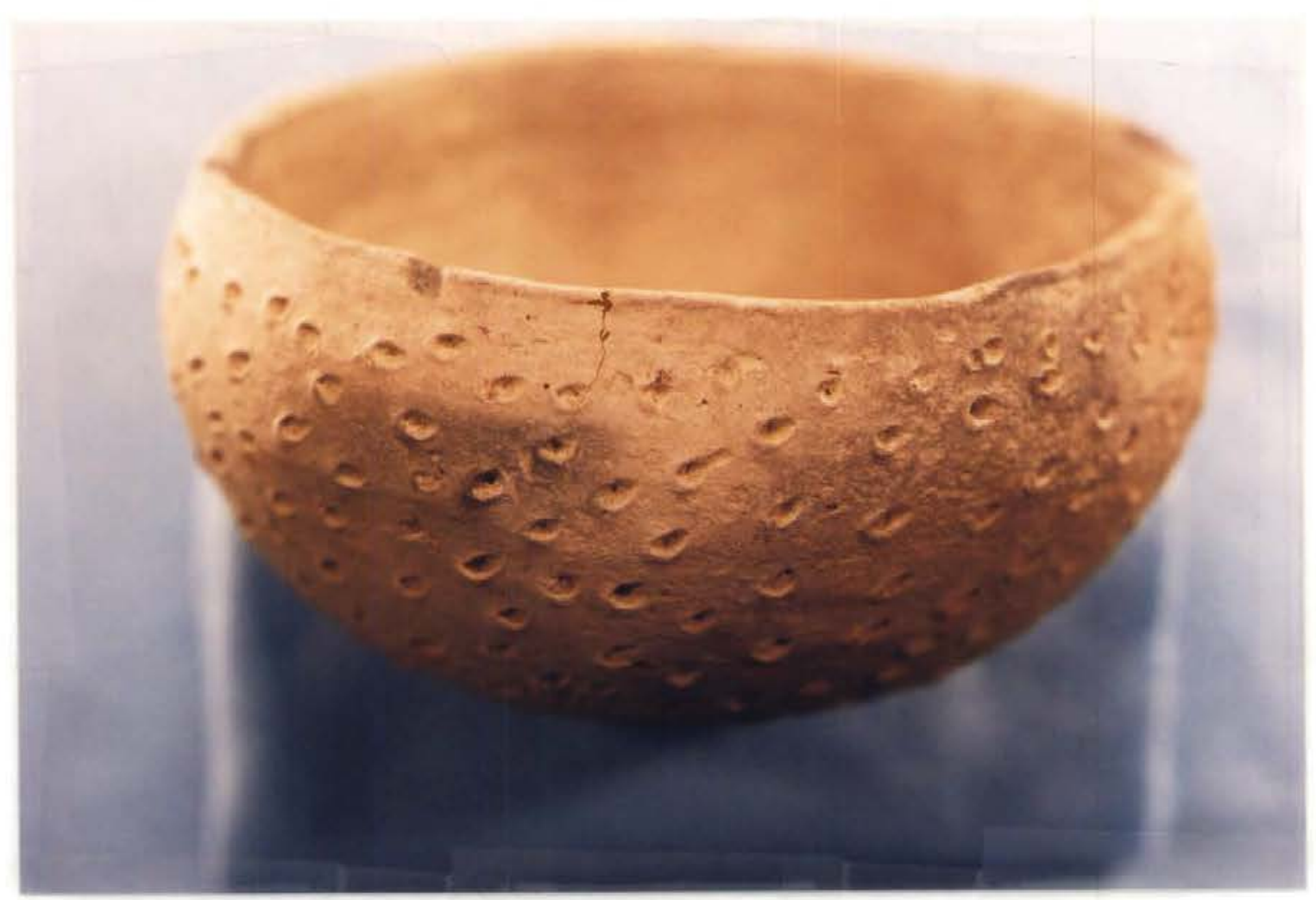

Figure 1. Vessel 1, Millsey Williamson site. 
Vessel 2 is a distinctive Natchitoches Engraved bone-tempered miniature bowl (Figure 2a). The bowl is decorated with a semi-circular motif repeated four times on the vessel (Figure 2b). The motif extends from near the rim to near the base, and consists of two semi-circular engraved lines with excised pendant triangles or tick marks, above which are hatched panels on either side of a small triangular element with excised pendant triangles or tick marks. Other than Simms Engraved, Natchitoches Engraved is the most common fine ware in Kinsloe phase assemblages (see Perttula 2007, this volume).

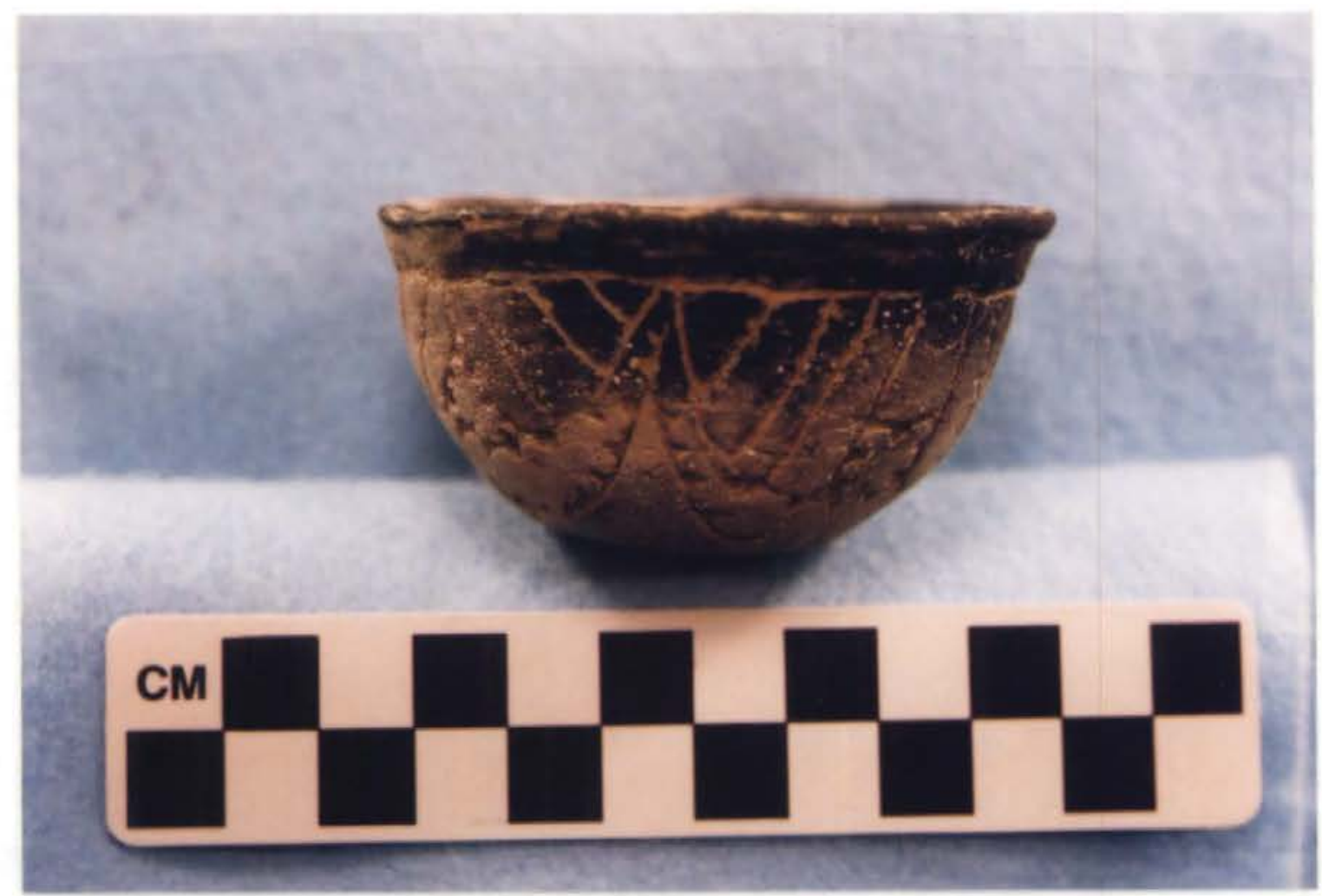

Figure 2a. Vessel 2, Millsey Williamson site, side view. 


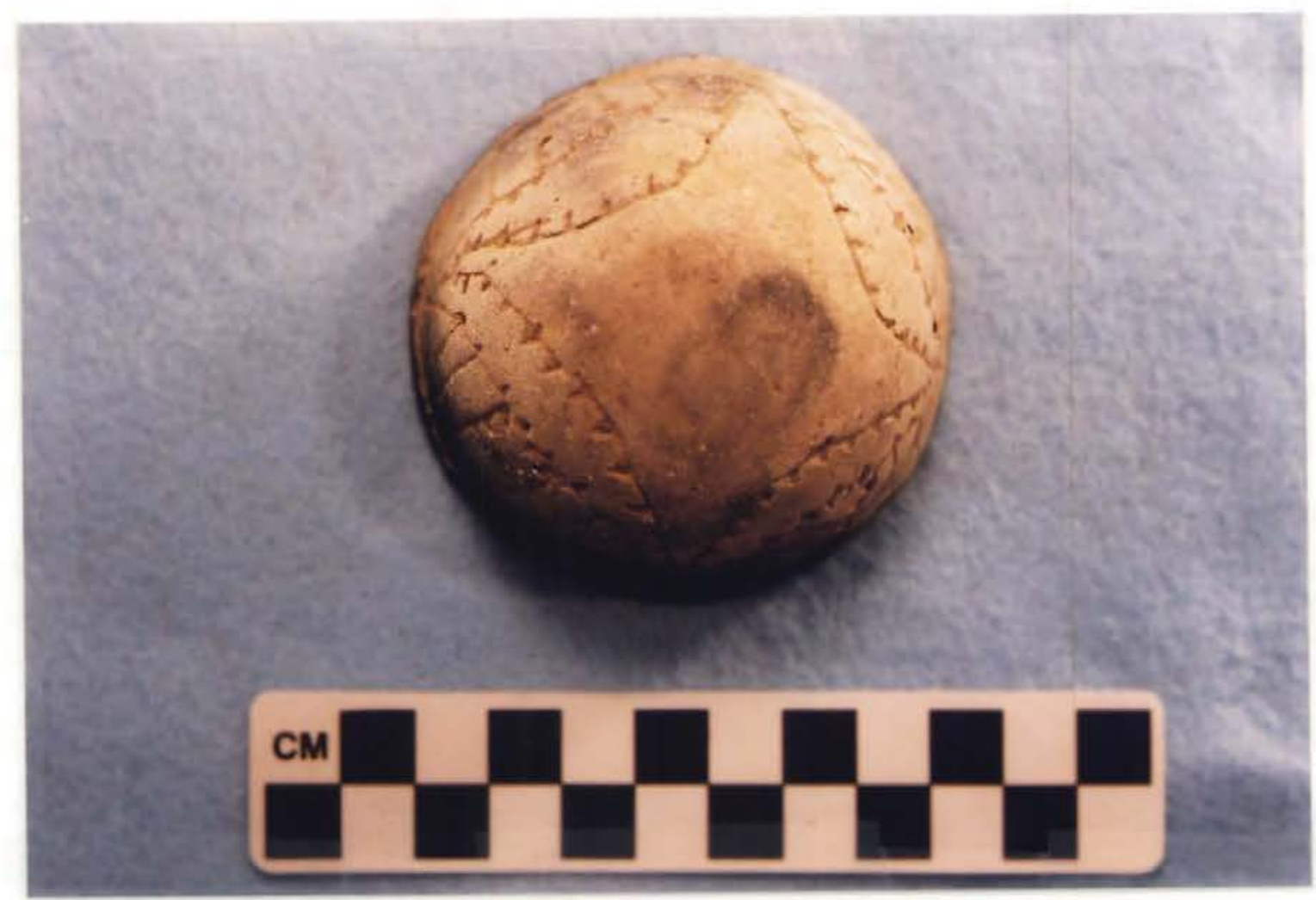

Figure 2b. Vessel 2, view of the bottom of the Natchitoches Engraved bowl.

Vessel 3 is a bottle with a spool neck that is swollen in the middle like many Keno Trailed and Natchitoches Engraved vessels (see Suhm and Jelks 1962: Plates 44a-e and $57 \mathrm{~h}$ ). The bottle is engraved on the body with sweeping upper and lower continuous scrolls, and there are hatched zones both above and below the scrolls (Figure 3 ). There is a red pigment smeared in the engraved lines.

If there were tick marks on the scrolls, we would be inclined to consider it a variety of Natchitoches Engraved. The sweeping continuous scrolls are indicative of Hodges Engraved, but the negative ovals are absent and the zones above and bclow the scrolls are not cross-hatched. On the basis of vessel shape, it resembles Hodges Engraved, var. Ouachita (see Weinstein et al. 2003:353 and Figure 131).

All three vessels from the Millsey Williamson site are small in size (Figure 4). They may have been funerary accompaniments for a child or juvenile. 


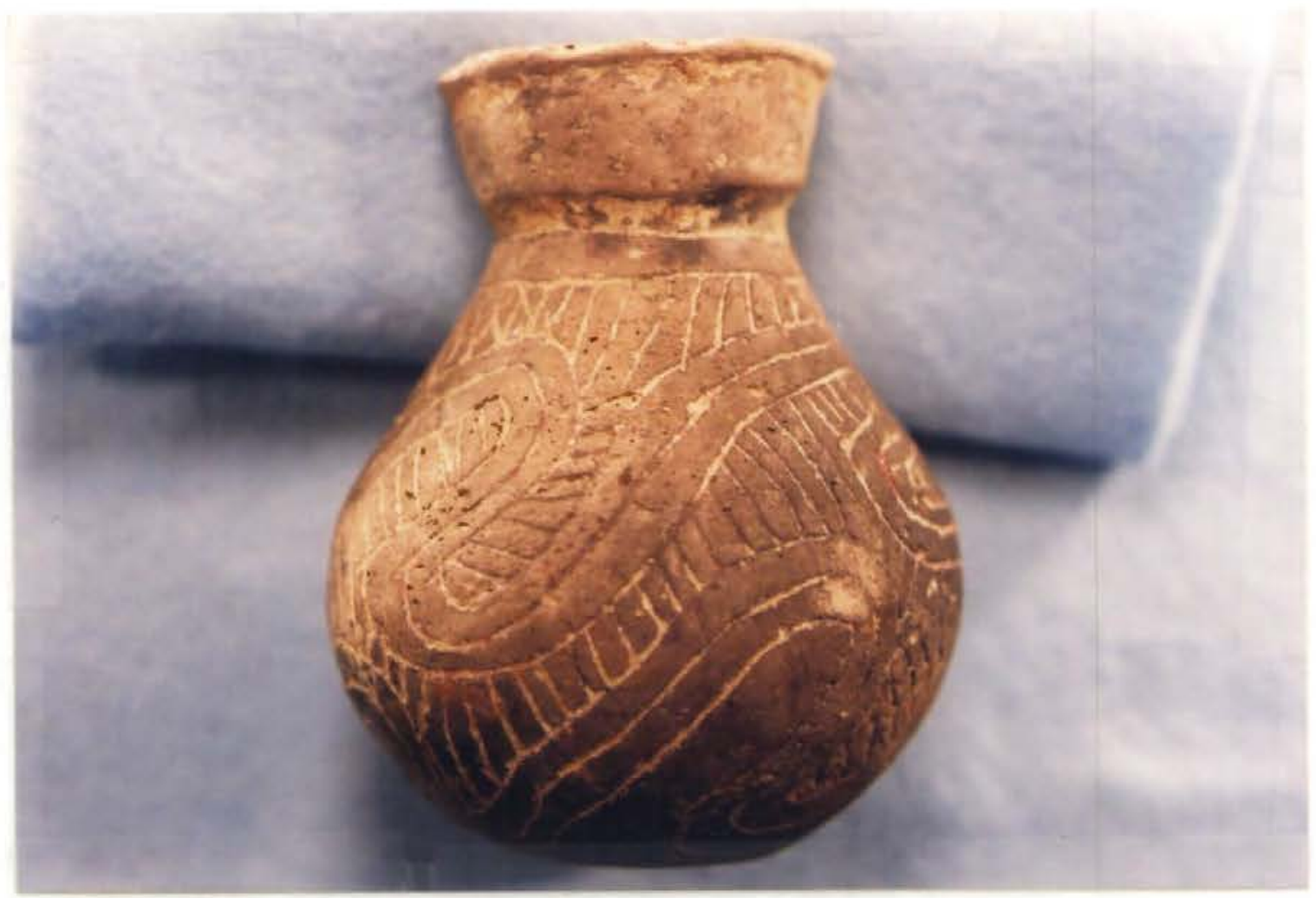

Figure 3. Vessel 3, possible Hodges Engraved or Natchitoches Engraved bottle, Millsey Williamson site.

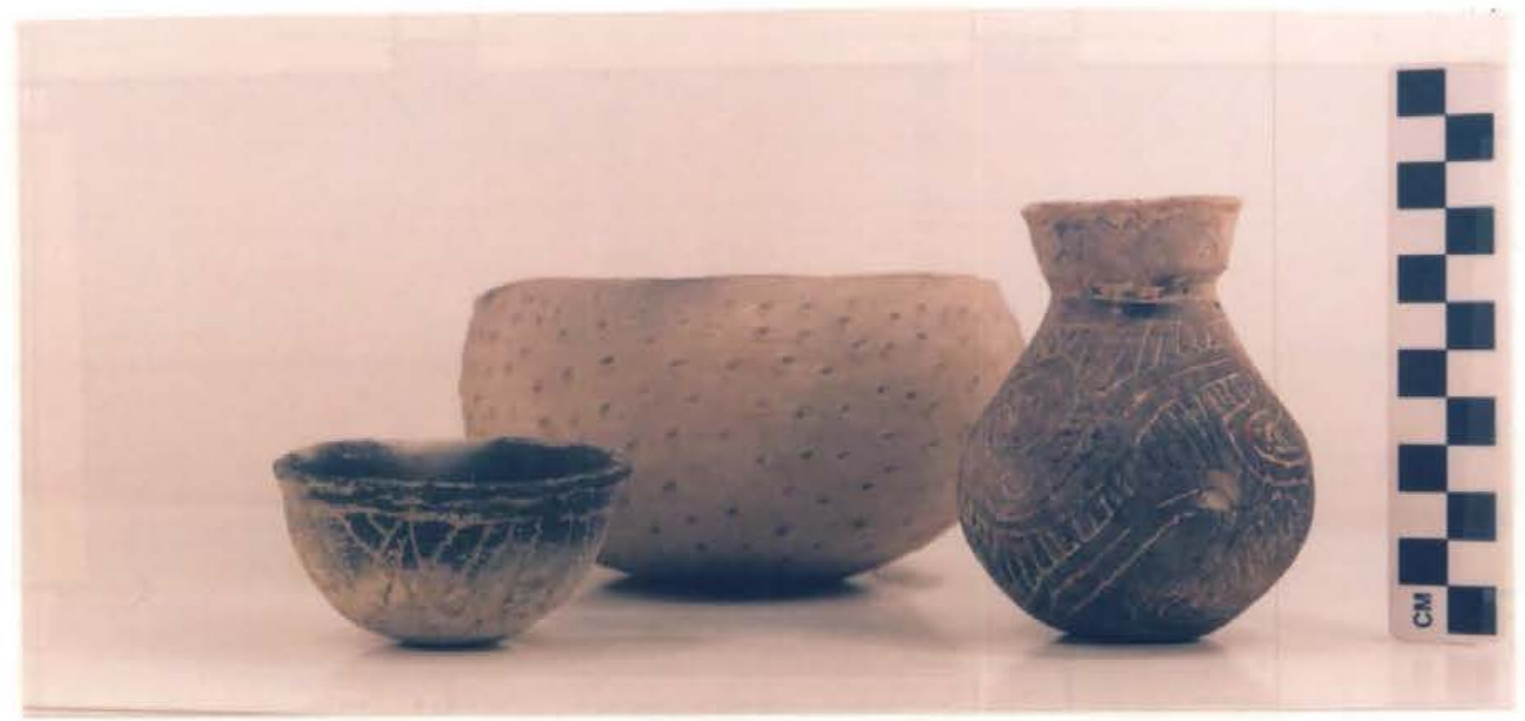

Figure 4. Vessels 1-3 from the Millsey Williamson site. 


\section{Vessel Sherds}

The 40 ceramic vessel sherds include 21 plain body and rim sherds and 19 decorated body sherds. The vessel sherd assemblage is distinctive because of the high percentage of bone-tempered (61.4\%) and shell-tempered (7.7\%) vessel sherds. In this part of northeastern Texas, the occurrence of shell-tempered vessels is exclusively found only in historic Caddo contexts. Jones (1968) notes that about $10 \%$ of the vessels in Kinsloe phase sites (including Natchitoches Engraved, Simms Engraved, var. Darco, Emory Punctated-Incised, and Henderson Plain vessels) are shell-tempered.

Among the decorated sherds are both utility wares $(\mathrm{n}=13,68 \%)$ and fine wares $(n=6,32 \%)$. Many of the utility ware sherds have either brushed (Bullard Brushed) or incised decorations (Maydelle Incised) on vessel bodies, or rows of tool punctations (Emory Punctated-Incised). The fine wares have engraved decorations, although five of the six have non-descript straight or parallel sets of lines (including one bottle sherd). The sixth engraved sherd, from a bowl or carinated bowl, has a cross-hatched triangular engraved element.

\section{Glass Beads}

There are seven different glass bead varieties in this collection from the Millsey Williamson site. The beads would have been worn as necklaces or sewn onto clothing.

All 36 of the beads are small (less than $4 \mathrm{~mm}$ in length and diameter) drawn beads (Kidd and Kidd 1970:48-49). They are either tubular-shaped with simple or monochrome bodies $(n=3)$; rounded with simple or monochrome bodies $(n=17)$; tubular-shaped with compound or multi-layered bodies $(\mathrm{n}=5)$; or rounded with compound or multi-layered bodies $(\mathrm{n}=11)$. The Kidd and Kidd (1970) bead varieties are listed in Table 2.

Table 2. Beads from the Millsey Williamson site.

\begin{tabular}{llll}
\hline Variety & Shape & Color & $\mathrm{N}$ \\
\hline Ia5 & tubular & white & 2 \\
Ia13 & tubular & light blue & 1 \\
IIa6 & round & black & 1 \\
IIa13 & round & white & 5 \\
IIa36 & round & light blue & 11 \\
IIIa3 & tubular & red outer color/black core & 5 \\
IVa2 & round & red outer color/light gray & 11 \\
& & core & \\
\hline
\end{tabular}


Bead colors are light blue, white, black, and red, with the latter color being the most popular in this small collection (Figure 5). The red beads with the black or light gray core are called Cornaline d'aleppo beads, and they are usually common in $18^{\text {th }}$ century sites in French Louisiana and Spanish Texas (Perttula 2005:90, 92).

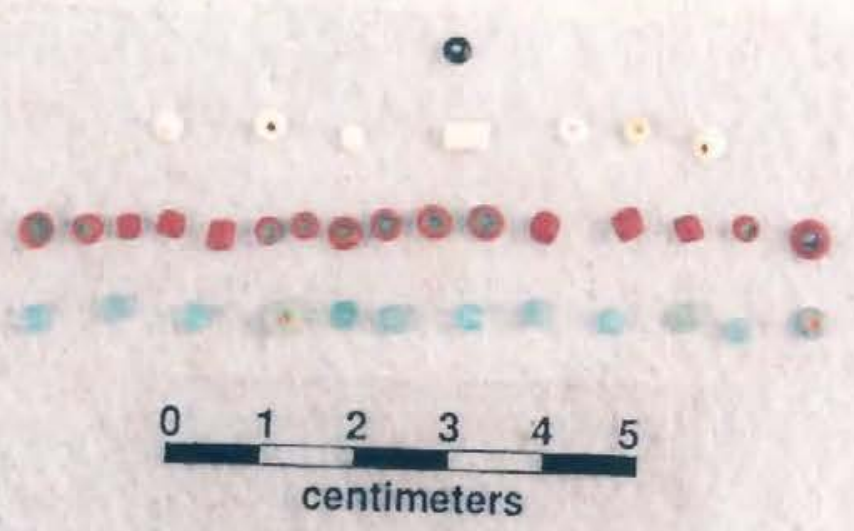

Figure 5. Beads in the Millsey Williamson site collection.

\section{Conclusions}

This documented collection from the Millsey Williamson site (41RK3) is from water-eroded contexts along the Martin Lake shoreline. The whole vessels indicate they are from an historic Caddo burial belonging to the Kinsloe phase (cf. Jones 1968). These Kinsloe phase sites are affiliated with the Nadaco Caddo. Our best estimate of the age of the collection-presuming the vessels and glass beads are from the same archaeological deposits - is ca. A.D. 1740-1790. This is based on the overall abundance of Cornaline d'aleppo beads among the glass beads (sec Perttula 2005: Table 2).

As long as shoreline erosion continues at Martin Lake, it is likely that other Nadaco Caddo burials and burial collections of artifacts will be exposed and reported from this important historic Caddo site in northeastern Texas.

\section{References Cited}

Jones, B. C.

1968 The Kinsloe Focus: A Study of Seven Historic Caddoan Sites in Northeast Texas. Master's thesis, Department of Anthropology, University of Oklahoma, Norman. 
Kidd, K. E. and M. A. Kidd

1970 A Classification System for Glass Beads for the Use of Field Archaeologists. Occasional Papers in Archaeology and History No. 1, pp. 45-89. National Historic Sites Service, National and Historic Parks Branch, Department of Indian Affairs and Northern Development, Ottawa, Ontario.

Perttula, T. K., with contributions by T. E. Emerson and R. E. Hughes

$200541 \mathrm{HO6} 4 / 41 \mathrm{HO} 65$, Late $17^{\text {th }}$ to Early $18^{\text {th }}$ Century Caddo Sites on San Pedro Creek in Houston County, Texas. Bulletin of the Texas Archeological Sociely 75:85-103.

Perttula, T. K.

2006 A Study of the Buddy Calvin Jones Collection from Northeast Texas Caddo Sites. Special Publication No. 6. Friends of Northeast Texas Archaeology, Austin and Pittsburg.

2007 Kinsloe Focus Artifact Assemblages and Nadaco Caddo. Journal of Northeast Texas Archaeology 26: 116-119.

Suhm, D. A. and E. B. Jelks (editors)

1962 Handbook of Texas Archeology: Type Descriptions. Special Publication No. 1, Texas Archeological Society, and Bulletin No. 4, Texas Memorial Museum, Austin.

Weinstein, R. A., D. B. Kelley, and J. W. Saunders (editors)

2003 The Louisiana and Arkansas Expeditions of Clarence Bloomfield Moore. University of Alabama Press, Tuscaloosa. 